\title{
LIETUVOS SVEIKATOS POLITIKOS RETŲ LIGŲ SRITYJE KRYPTYS: DABARTINE TEISINE PADĖTIS IR PROBLEMOS
}

\author{
Indrè Špokienė \\ Mykolo Romerio universiteto Teisès fakulteto \\ Teisès filosofijos ir istorijos katedra \\ Ateities g. 20, LT-08303 Vilnius \\ Telefonas (+370 5) 2714697 \\ Elektroninis paštas indrespokiene@gmail.com \\ Pateikta 2014 m. rugpjūčio 25 d., parengta spausdinti 2014 m. spalio 5 d.
}

doi:10.13165/SPV-14-2-7-09

\section{Santrauka}

Retu ligu srityje skiriamos dvi pagrindinès nacionalines sveikatos politikos kryptys. Pirmoji - prevencinés priemonès (visuotiné naujagimiu patikra dèl retu ligu; genetinis konsultavimas), antroji - sisteminga pagalba sergantiesiems (asmens sveikatos priežiūros paslaugu sistema; pacientu siuntimas konsultuotis ir gydytis i užsienį; vaistu prieinamumas). Be abejo, svarbios ir kitos priemonès, tačiau ju taikymo teisinis reglamentavimas retu ligu atveju nèra specifinis. Todèl šiame straipsnyje apsiribojama tik paminètu veiklu teisinio reguliavimo ir etiniu ypatumu tyrimu: pristatoma ir nagrinèjama dabartiné padètis ir pokyčiai nacionalinèje teisejje, išryškinamos ir svarstomos problemos, su kuriomis susiduria retomis ligomis sergantys pacientai bei valstybe.

Reikšminiai žodžiai: retos ligos, retieji vaistai, Lietuvos sveikatos politika retu ligu srityje, retu ligu politikos kryptys, retomis ligomis sergančiu pacientų teisès.

\section{Ivadas}

Retos ligos - tai ypač mažai paplitusios gyvybei pavojų keliančios arba lètai sekinančios ligos, kuriomis Europos Sąjungoje (toliau - ES) serga ne daugiau 
kaip 5 iš 10000 asmenų $^{1}$. Dauguma retų ligų yra genetinès ligos (jos sudaro 80 proc.), o likusios - retos véžio formos, autoimuninès ligos, igimtos raidos anomalijos, toksinès ir infekcinès ligos ${ }^{2}$.

Galima skirti dvi pagrindines sveikatos politikos kryptis retų ligų srityje. Pirmoji - tai prevencinès priemonès (visuotiné naujagimių patikra dèl retų ligų; genetinis konsultavimas), antroji - sisteminga pagalba sergantiesiems ir ju artimiesiems (asmens sveikatos priežiūra, vaistų prieinamumas, pacientų siuntimas konsultuotis ir gydytis ị užsienį). Tinkamas šių sričių teisinis reguliavimas ir igyvendinimas, taip pat kitos sveikatos politikos priemonès (tokios kaip, pavyzdžiui: parama pacientų organizacijoms; slaugos, medicininès reabilitacijos, paliatyvios pagalbos prieinamumas; informacijos pacientams ir visuomenei sklaida) sudaro prielaidas ịgyvendinti retomis ligomis sergančių pacientų teisę i kokybišką sveikatos priežiūrą.

Prieš penkerius metus atlikus retomis ligomis segančių pacientų padėties Lietuvoje teisinị vertinimą buvo konstatuota, kad teisinès ir praktinės nacionalinès sveikatos politikos iniciatyvos bei veiksmai retų ligų ir retųjų vaistų ${ }^{3}$ srityje yra nepakankami: tam tikros Lietuvos teisès aktų nuostatos ir procedūros i̇vertintos kaip nepagrịstai ribojančios pacientų teisę ị kokybišką sveikatos priežiūrą. Tuomet siūlyta: tobulinti nacionalinę teisinę bazę dèl vaistų retoms ligoms gydyti prieinamumo; aiškiau reglamentuoti ir taip skaidrinti retoms ligoms gydyti skirtų vaistų kompensavimo kriterijus ir tvarką; detaliai reglamentuoti sveikatos priežiūros specialistų bendradarbiavimą vykdant retų ligų diagnostiką, pacientų konsultavimą ir gydymą; kurti retų ligų konsultacinius centrus; parengti ir priimti nacionalinị veiksmų dèl retų ligų planą; didinti informacijos apie retas ligas sklaidą ir kt. ${ }^{4}$

Kokia padètis yra šiandien, kokios didžiausios problemos? Straipsnyje atliekamo tyrimo tikslas - ištirti nacionalinès sveikatos politikos retų ligų srityje, vykdomos dviem anksčiau minètomis kryptimis, teisinius ir etinius ypatumus. Tikslui igyvendinti keliami šie uždaviniai: 1) atskleisti pagrindinių veiklų (priemonių), susijusių su retų ligų prevencija ir pagalba retomis ligomis sergantiems pacientams, dabartinio teisinio reguliavimo ypatumus nacionalineje teiseje; 2) išryškinti ir apsvarstyti sveikatos politikos priemonių retų ligų srityje etines ir

Europos Parlamento ir Tarybos 1999 m. gruodžio 16 d. reglamentas Nr. 141/2000 „Dèl retųjų vaistų“. [2000] OL L 18/1.

2 McCabe, C.; Bergmann, L.; Bosanquet, N.; Ellis, M.; Enzmann, H.; von Euler, M., et al. Market and patient access to new oncology products in Europe: a current, multidisciplinary perspective. Annals of Oncology. 2009, 20(3): 408.

3 Retieji vaistai - tai vaistai, įrašyti ị Europos Bendrijos retųjų vaistų registrą (angl. Community register of designated orphan medicinal products), skirti retoms ligoms ir büklems gydyti.

4 Špokienè, I. Legal assessment of current situation on orphan patients in Lithuania. Medicina. 2008, 44(8): 571-576; Špokienè, I. Retuju vaistu prieinamumo reglamentavimas sveikatos teisejje. Daktaro disertacija (01 S). Vilnius: MRU, 2009, p. 169. 
teisines problemas. Retų ligų kaip visuomenès sveikatos problemos sprendimas jau daugiau nei dešimtmetị yra vienas ilgalaikių ES politikos prioritetų, o nuo 2014 metų ir privaloma visų valstybių narių sveikatos politikos dalis. Lietuvoje nuo 2012 metų spalio galioja Nacionalinis veiklos, susijusios su retomis ligomis, planas 5 . Todèl straipsnyje atliekamas tyrimas, atskleidžiantis nacionalinès politikos retų ligų srityje turinị bei pokyčius, aktualus ir nacionaliniu, ir regioniniu mastu.

Pagrindiniai tyrimo metodai: loginis, analitinis, sisteminė šaltinių (ES ir Lietuvos teisès aktų, teismų praktikos, Lietuvos ir užsienio autorių mokslinių publikacijų) analizè. Atliekant šaltinių paiešką (lyginant su situacija prieš penkerius metus) pastebėta socialinių mokslų atstovų dėmesio retų ligų tematikai augimo tendencija. Lietuvoje teisiniu aspektu 2010 metais išanalizuota neregistruotu retoms ligoms gydyti skirtų vaistų prieinamumo problema ${ }^{6}$. Užsienio publikacijų duomenų bazėse jau galima rasti mokslinių straipsnių, kuriuose nagrinejjami ịvairūs etiniai ir socialiniai su retomis ligomis susiję aspektai ${ }^{7}$, mokslininkai daugiau tyrinejja ir ekonominius bei teisinius retųjų vaistų prieinamumo klausimus ${ }^{8}$. Nepaisant to, greičiausiai dèl tarpdalykiškumo su retomis ligomis sergančiu pacientų teisėmis susijusių problemų ištirtumas išlieka nedidelis. Iki šiol Lietuvoje sistemiškai nacionalinès politikos krypčių retų ligų srityje teisiniai bei etiniai ypatumai bei problemos, išskyrus retųjų vaistų prieinamumo aspektą, nebuvo nagrinèti. Tuo tarpu atsižvelgiant ị didelę retomis ligomis sergančių pacientų ir jų artimųjų bendruomenę bei tokias nūdienos tendencijas kaip didẻjančios retų ligų diagnostikos ir prevencijos galimybès, naujų gydymo būdų bei naujų retoms ligoms gydyti skirtų vaistų rinkoje atsiradimas, ginčų dèl jų prieinamumo augimas, akivaizdu, kad teisininkams bei sveikatos politikos formuotojams būtina aktyviai diskutuoti ir spręsti su retomis ligomis sergančių pacientų teisėmis susijusius klausimus ir problemas.

Lietuvos Respublikos sveikatos apsaugos ministro 2012 m. spalio 18 d. ịsakymas Nr. V-938 „Dèl nacionalinio veiklos, susijusios su retomis ligomis, plano patvirtinimo“. Valstybès žinios. 2012, Nr. 124-6239.

6 Špokienė, I. Retomis ligomis sergančių pacientų teisinès galimybès gydytis neregistruotais vaistais. Socialiniu mokslu studijos. 2010, 2(6): 207-225.

7 Barrera, L.; Gilberto, C. G. Ethical Aspects on Rare Diseases. In Posada de la Paz, M.; Groft, M.; Groft, S (ed.). Rare Diseases Epidemiology, Advances in Experimental Medicine and Biology. 2010, 686: 493-511; Kole, A.; François, F. Rare diseases social epidemiology: analysis of inequalities. In Posada de la Paz, M.; Groft, M.; Groft, S (ed.). Rare Diseases Epidemiology, Advances in Experimental Medicine and Biology. 2010, 686: 223-250; Krajnovic, D. Ethical and social aspects of rare diseases. Filozofija/Društvo. 2012, XXIII (4): 32-48.

8 Supra note 5.

9 Duomenys, kiek Lietuvoje žmonių serga retomis ligomis, nèra susisteminti. Atsižvelgiant $\mathfrak{i}$ statistinị retų ligų paplitimo visuomenéje rodiklį, siekiantị apie 6-8 procentus, preliminariai skaičiuojama, kad tokių asmenų Lietuvoje yra apie 200 000. Tumienè, B.; Kučinskas, V. Retosios ligos Lietuvoje ir Europoje. Gydymo menas. 2008, 11/12: 25-27. 


\section{Retų ligų prevencijos teisinis reguliavimas Lietuvoje: ypatumai ir problemos}

\subsection{Visuotinio naujagimių tikrinimo dèl retų ligų teisinis reguliavimas}

2009 m. birželio 8 d. Tarybos rekomendacijoje dèl retų ligų srities veiksmų valstybės narès skatinamos atlikti ir tobulinti visuotinę naujagimių patikrą dèl igimtų ligų ${ }^{10}$. Šis diagnostikos būdas leidžia anksti nustatyti kai kurias ligas ir pradèti gydymą bei gyvenimo būdo korekciją dar iki klinikinių ligos simptomų pasireiškimo, užkertant kelią komplikacijoms ${ }^{11}$. Kiekviena valstybė ligų, dèl kurių taikoma visuotinè patikra, sąrašą nustato atsižvelgdama ị savo finansines galimybes, todèl patikros mastai šalyse skiriasi.

Lietuvoje, turinčioje apie tris milijonus gyventojų, kasmet gimsta apie 26 000-30 000 naujagimių. Visuotinè naujagimių patikra atliekama dèl fenilketonurijos (nuo 1975 m.) ir igimtos hipotirozès (nuo 1993 m.) ${ }^{12}$. Negydant ar diagnozavus per vèlai šios ligos sukelia sunkų protinị atsilikimą ir fizinio vystymosi sutrikimus. Naujagimių tikrinimas dèl šių retų ligų mūsų šalyje yra nemokamai siūlomas visai tikslinei populiacijai, tačiau tyrimas nèra privalomas. Naujasis „Visuotinio naujagimių tikrinimo dèl igimtų medžiagų apykaitos ligų tvarkos aprašas ${ }^{“ 13}$ numato gimdyvès arba naujagimio atstovo atsisakymo leisti tikrinti naujagimį dèl igimtų medžiagos apykaitos ligų tvarką ir formą. Čia nurodoma būtinybè îspèti minètus subjektus apie pavèluotos diagnozės pasekmes vaiko sveikatai ir gyvybei. Oficialių duomenų nèra, tačiau greičiausiai atsisakymo atvejų pasitaiko, nors ir nedažnai, nes Vilniaus universiteto ligoninės Santariškių klinikų Medicininės genetikos centro, atsakingo už šios patikros vykdymą, darbuotojai informuoja, kad Lietuvoje šis tikrinimas praktiškai igyvendinamas beveik šimtu procentų, taigi bent jau kol kas pasižymi universalumu.

Remiantis statistika kasmet fenilketonurija ir hipotirozè nustatoma 8-12 naujagimių. 1975-2011 metais Lietuvoje dèl fenilketonurijos patikrinti 1271503 naujagimiai, iš viso diagnozuoti 166 hiperfenilalaninemijos ir fenilketonurijos atvejai. 1993-2011 metais dèl igimtos hipotirozés patikrinta 400197 naujagimiai, iš viso diagnozuotas 121 igimtos hipotirozès atvejis ${ }^{14}$. Šiems pacientams valstybẻ laiduoja specifini gydymą. Sergantiesiems fenilketonurija teisès aktais numaty-

10 Council Recommendation of 8 June 2009 on an action in the field of rare diseases. [2009] OJ C 151. Preambules 19 punktas, 17 d) dalis.

11 Supra note 5, 33 punktas.

12 Lietuvos Respublikos sveikatos apsaugos ministro 2014 m. gegužès 22 d. ịsakymas Nr. V-601 „Dèl Visuotinio naujagimių tikrinimo dèl igimtų medžiagų apykaitos ligų tvarkos aprašo patvirtinimo“. Valstybès žinios. 2014, Nr. 2014-05759.

$13 \quad I b i d ., 14$ punktas.

14 Supra note 5. 
tas specialiosios paskirties maisto produktų, kurių sudètyje yra mažesnis baltymų ir fenilalanino kiekis, įsigijimo išlaidų kompensavimas ${ }^{15}$. Sergantiesiems igimta hipotiroze kompensuojami vaistai. Tyrimo atlikimo išlaidos kompensuojamos Privalomojo sveikatos draudimo fondo (toliau - PSDF) biudžeto lěšomis. Vis dèlto reikia pasakyti, kad Lietuva yra tarp tų ES šalių, kur tikrinama dèl mažiausio retų ligų skaičiaus. 2010 metų duomenimis, dèl vienos ar dviejų ligų tikrinama tik dar 9 šalyse ${ }^{16}$. Tuo tarpu kai kuriose turtingose Europos šalyse visuotinai naujagimiai tikrinami dèl iki 29 paveldimų ligų ${ }^{17}$. Daugelį jų diagnozavus laiku galima efektyviai gydyti.

Nacionaliniame veikos, susijusios su retomis ligomis, plane iki 2017 metu numatyta peržiūrèti ligų, kurioms taikoma visuotinè naujagimių patikra, sąrašą, papildyti ji atsižvelgiant i finansines PSDF biudžeto galimybes ir visuotinès naujagimių patikros kriterijus ${ }^{18}$.

\subsection{Genetinio konsultavimo teisinis reguliavimas}

Statistiškai per metus Lietuvoje užregistruojama apie 500-600 paveldimų ligų ir igimtų raidos anomalijų atvejų ${ }^{19}$. „Genetinis konsultavimas - tai informacijos apie ligos ar požymio paveldimą pobūdị perdavimas konsuluojamajam asmeniui, tuo besidominčiai šeimai “20. Šeimos, kurių giminèje esama paveldimų ligų, kviečiamos konsultuotis dar iki pastojimo. Genetinis konsultavimas - tai specializuota medicinos pagalbos, kurią teikia gydytojas genetikas, rūšis, kai diagnozuojamos paveldimos ligos, igimtos anomalijos ${ }^{21}$, sudarančios didžiąją retų ligų dalí. Neatsiejama genetinio konsultavimo dalis yra prenatalinè diagnostika. Tai embriono ar vaisiaus susirgimų diagnostika iki gimimo, kuria sie-

15 Lietuvos Respublikos sveikatos apsaugos ministro 2000 m. spalio 6 d. ịsakymas Nr. 529 „Dèl Medicinos pagalbos priemonių sąrašo patvirtinimo“. Valstybès žinios. 2000, Nr. 85-2609; 2009, Nr. 141-6237.

16 Burgard, P.; Cornel, M.; Di Filippo, F.; Haege, G., and etc. EU tender "Evaluation of population newborn screening practices for rare disorders in Member States of the European Union". Short Executive Summary of the Report on the practices of newborn screening for rare disorders implemented in Member States of the European Union, Candidate, Potential Candidate and EFTA Countries [interaktyvus]. 2012 [žiūrèta 2014-08-06] <http://ec.europa.eu/eahc/documents/news/ Summary_20120110.pdf>.

17 Ibid.

18 Supra note 5.

19 Utkus, A. Retosios ligos, ju fenomika ir genetinis konsultavimas. Habilitacijos procedūrai teikiamų darbų apžvalga. Biomedicinos mokslai (medicina) (07B) [interaktyvus]. Vilnius, 2009 [žiūrèta 2014-08-06]. <http://vddb.library.lt/fedora/get/LT-eLABa-0001:E.02 2009 D_20090526_ 11135229090/DS.005.0.01.ETD>.

$20 \quad$ Ibid., p. 8-9.

21 Lietuvos Respublikos sveikatos apsaugos ministro 2003 m. balandžio 14 d. įsakymas Nr. V-220 „Dèl Lietuvos medicinos normos MN 56:2003 „Gydytojas genetikas. Teisès, pareigos, kompetencija ir atsakomybè" patvirtinimo“. Valstybès žinios. 2003, Nr. 43-1983. 4.3. punktas. 
kiama nustatyti tam tikrus jo raidos nukrypimus ar polinkị jų turèti. Dèl sparčios biotechnologijų pažangos žmogaus genetikos srityje atsiradus galimybei kai kurias genetines ligas aptikti ir identifikuoti jau ankstyvosiose embriono vystymosi stadijose, jų diagnostika tapo prenatalinès diagnostikos tikslu.

Preimplantacinè diagnostika yra viena prenatalinès diagnostikos formų, kai dirbtinio apvaisinimo procedūros metu gauto embriono genetiniai tyrimai atliekami prieš perkeliant embrioną i gimdą. Nors kol kas ši procedūra brangi, netiksli, in vitro metodas kai kuriose šalyse jau pasitelkiamas ne tik nevaisingumo gydymo atvejais, bet pageidaujamas ir vaisingų porų siekiant eliminuoti genetinių ligų perdavimo palikuonims riziką ${ }^{22}$. Kadangi šio metodo taikymo teisinis reguliavimas paliekamas kiekvienos valstybès prerogatyvai, valstybių pozicijos dèl preimplantacinès diagnostikos skiriasi: varijuoja nuo liberalios pragmatiškos pozicijos (atsižvelgiant ị sunkios ligos, aborto, o kartu ir „,naštos“ šeimai bei visuomenei išvengimo privalumus) iki griežto draudimo (argumentuojant tuo, kad embrionų selekcija vertinama kaip eugenika) ${ }^{23}$. Taigi kai kuriose valstybėse preimplantacinė diagnostika yra draudžiama (pvz., Austrijoje, Šveicarijoje), kitur, kaip, pavyzdžiui, Prancūzijoje, Danijoje, Švedijoje, Jungtinèje Karalystėje, Izraelyje $^{24}$ - šis metodas ịteisintas, tačiau procedūrą leidžiama atlikti tik medicininiais tikslais ir egzistuojant tam tikroms sąlygoms (didelẻ genetinės ligos paveldimumo rizika, ligos sunkumas, neišgydomumas ir pan.). Lietuvoje šio metodo taikymas dèl tam tikrų embriono apsaugos etinių ir teisinių prieštaravimų nereglamentuotas. Vis dèlto spręsti, kad Lietuva šio metodo taikymo atžvilgiu kol kas laikosi atsargios pozicijos, leidžia Lietuvos Respublikos biomedicininių tyrimų etikos įstatymas ${ }^{25}$, kuris įtvirtina vieną griežčiausių Europoje embriono apsaugos režimą. Embriono sąvoka čia apibrěžta kaip ,žmogaus organizmo vystymosi stadija nuo apvaisinimo momento (zigotos susidarymo) iki moters aštuntos nèštumo savaitès pabaigos" ( 2 str. 4 d.). O ịstatymo 3 straipsnis ịsakmiai nurodo, kad „su žmogaus embrionais leidžiama atlikti tik klinikinius stebejjimus (neinvazinius tyrimus). Kiti biomedicininiai tyrimai su žmogaus embrionais, taip pat jų kūrimas biomedicininių tyrimų tikslais yra draudžiami. Su vaisiumi leidžiama atlikti tik tuos biomedicininius tyrimus, kurių numatoma nauda tiriamam vaisiui viršija medicininę riziką“. Igyvendinant šio įstatymo nuostatas, buvo papildytas Baudžiamojo kodekso $308^{1}$ straipsnis, numatant sankcijas už

${ }^{22}$ Zielonka, D.; Marcinkowski, J. T.; Klimberg A. J. Health policy and legal regulations concerning the functioning in society of individuals burdened with Huntington's disease and other rare diseases. Journal of Pre-Clinical and Clinical Research. 2013, 7(1): 27-31.

23 Ibid.

24 Isasi, R. M.; Knoppers B. M. Regulatory approaches to reproductive genetic testing. Human Reproduction. 2004, 19(12): 2695-2701.

25 Lietuvos Respublikos biomedicininių tyrimų ịstatymas. Valstybės žinios. 2000, Nr. 44-1247. 
draudžiamų biomedicininių tyrimų su žmogumi ar žmogaus embrionu atlikimą, o pati veikla kvalifikuota kaip nusikaltimas dorovei ${ }^{26}$.

Kiti invaziniai ir neinvaziniai prenatalinès diagnostikos metodai, kuriuos galima taikyti pacientès néštumo metu, yra reglamentuoti 2005 metų birželio 23 d. sveikatos apsaugos ministro ịsakymu Nr. V-52227. Čia numatyta, kad šeimos gydytojas arba kitos profesinès kvalifikacijos gydytojas, nustatęs, kad yra indikacijų konsultuoti dèl paveldimų ligų ir igimtų anomalijų bei teikti vaisiaus chromosominių ligų rizikos biocheminių žymenų nustatymo pirmąji nėštumo trimestrą paslaugą, informuoja apie tai pacientę ar jos šeimos narị ir paaiškina apie galimybę gauti šias paslaugas ${ }^{28}$. Yra maždaug 14 priežasčių, dèl ko moterị reikètų genetiškai tirti valstybės léšomis: tai paveldimos anomalijos šeimoje, gimininga santuoka, du ir daugiau persileidimų moters vaisingumo istorijoje, taip pat jei moteris jau anksčiau yra gimdžiusi kūdikị su paveldima ar chromosomų liga, arba šio néštumo metu vartojo vaistus ar chemikalus, galëjusius pažeisti vaisių. Minètų paslaugų išlaidos yra kompensuojamos iš PSDF ${ }^{29}$. Didžiausia PSDF lèšomis tiriamų nėščiųjų dalis ị genetikus kreipiasi dèl amžiaus, nes Lietuvoje visoms néšciosioms, kurioms gimdymo metu sukanka 35 metai ir vyresnems arba jei kūdikio tèvas yra 42 metų amžiaus, rekomenduojama gydytojo genetiko konsultacija $^{30}$. Jeigu nèra indikacijų, genetinè konsultacija ir visi tyrimai, jei néščioji jų pageidauja, atliekami mokamai. Antrinè igimtų anomalijų profilaktika - tikslinè prenatalinè diagnostika - Lietuvoje vykdoma šiomis kryptimis: vaisius tiriamas ultragarsu visais něštumo trimestrais, ̨̇vertinama individuali rizika vaisiui sirgti chromosomine liga, atitinkamais metodais nustatomas vaisiaus kariotipas / genotipas, tiriami rizikos grupès něšciųjų kraujo serumo žymenys I ir / ar II něštumo trimestruose, atliekami molekuliniai genetiniai vaisiaus tyrimai ${ }^{31}$.

Prenatalinè diagnostika kaip neatsiejama néščiosios sveikatos priežiūros dalis padeda išvengti nepagrịsto nerimo dèl būsimo vaiko sveikatos būklès, nepa-

26 Lietuvos Respublikos baudžiamasis kodeksas. Valstybès žinios. 2000, Nr. 89-2741.

27 Lietuvos Respublikos sveikatos apsaugos ministro $2005 \mathrm{~m}$. birželio 23 d. ịsakymas Nr. V-522 „Dèl Žmogaus genetikos paslaugų, apmokamų iš Privalomojo sveikatos draudimo fondo biudžeto, sąrašo ir jų bazinių kainų patvirtinimo“. Valstybés žinios. 2005, Nr. 90-3380.

28 Siuntimo dèl paveldimu ligų ir igimtų anomaliju (su visišku laboratoriniu ištyrimu) bei vaisiaus chromosominių ligų rizikos bei biocheminių žymenų nustatymo pirmąji nėštumo trimestrą tvarkos aprašas, patvirtintas Lietuvos Respublikos sveikatos apsaugos ministro 2005 m. birželio 23 d. îsakymu Nr. V-522, supra note 25.

29 Lietuvos Respublikos sveikatos apsaugos ministro 2008 m. sausio 17 d. ịsakymas Nr. V-49 „Dèl Imunotipavimo, genetinio, kraujo krešejimo veiksnių tyrimų, apmokamų iš Privalomojo sveikatos draudimo fondo biudžeto, atlikimo reikalavimų ir apmokẻjimo sąlygų aprašo patvirtinimo“. Valstybès žinios. 2008, Nr. 12-406.

30 Šios grupès moterys pastaraisiais metais Lietuvoje sudaro apie 11 proc. visų gimdyvių.

31 Lietuvos Respublikos sveikatos apsaugos ministro 2008 m. gegužès 29 d. ịsakymas Nr. V-513 „Dèl Valstybinès šeimos sveikatos 2008-2010 metų programos patvirtinimo“. Valstybès žinios. 2008, Nr. 65-2475. 
grịstų abortų dẻl baimès gimdyti, pavyzdžiui, pastojus vyresniame amžiuje. Vis dèlto šios praktikos populiarejimas ir retos embriono ar vaisiaus ligos diagnozès „,išeitys" kelia tam tikrų etinių bei teisinių klausimų.

\subsection{Retų ligų prevencijos etinio bei teisinio vertinimo problemos}

Ar etiniu bei teisiniu požiūriu dabartinę nacionalinę retų ligų prevencijos politiką galima ịvertinti palankiai, vienareikšmiškai atsakyti sunku. Dẻl visuotinio naujagimių tikrinimo kaip retų ligų prevencijos priemonès vertinimo didesnių etinių prieštaravimų ir problemų, išskyrus tai, jog Lietuvoje naujagimiai tiriami dẻl itin mažo retų ligų skaičiaus, nekyla. Šio metodo taikymas daugiausia susijęs su finansine našta valstybei. Tuo tarpu kitų prevencijos priemonių - t. y. prenatalinès diagnostikos metodų taikymo dabartinio teisinio reguliavimo Lietuvoje vertinimas ir problemos, kurias įžvelgsime, priklauso nuo to, kuria etikos tradicija vadovausimès, kieno - motinos, negimusio vaiko ar visuomenès interesus palaikysime. Čia susikerta skirtingų individų skirtingos teisès ir interesai: suaugusių individų noras susilaukti sveikų palikuonių, o visuomenès - turèti sveiką, darbingą visuomenès narị ir dar negimusio vaiko (embriono mégintuvèlyje / embriono, atsiradusio natūralaus apvaisinimo atveju / žmogaus vaisiaus ${ }^{32}$ ) žmogiškasis orumas bei teisès.

Atkreiptinas dèmesys, kad iš esmès prenatalinè diagnostika nèra atliekama siekiant naudos dar negimusiam vaikui. Diagnostikos tikslas nèra sudaryti galimybę embrioną ar vaisių gydyti, nes terapijos galimybès įmanomos išimtinai retais atvejais. Šios ankstyvosios diagnostikos formos tikslas yra nustatyti vaisiaus raidos nukrypimus nuo biologinès - struktūrinès ar funkcinès normos. Deja, daugeliu atvejų veiksmai, kurių tuomet galima imtis (priklausomai nuo teisinio reguliavimo ir taikyto diagnostikos metodo), vadinamosios ,diagnozès išeitys“ - tai embriono „išbrokavimas“ arba néštumo nutraukimas medicininiu pagrindu. Taigi „diagnozuota ir neišgydoma dar negimusio žmogaus liga ar polinkis ja sirgti galiausiai neišvengiamai reikalauja nuspręsti, ar jis vertas gyventi“"33. Embriono ar vaisiaus pasmerkimo žūčiai moralinis, etinis, teisinis vertinimas priklauso nuo visuomenès ir valstybès bei kiekvieno iš mūsų atsakymo sau, kas yra negimęs vaikas, nuo terminų ,vaikas iki gimimo“, „žmogus“ ir „žmogaus gyvybë“ interpretavimo.

Nors šiandienos mokslas neginčijamai įrodė, kad žmogaus gyvybè atsiranda nuo apvaisinimo momento, tarptautinè teisè ị anksčiau išvardintus klausimus vienareikšmio atsakymo nepateikia. Nė viename žmogaus teises reglamentuo-

32 Laikotarpis iki žmogaus gimimo vadinamas prenataliniu: nuo zigotos susidarymo iki 8 savaitès žmogus vadinamas embrionu, nuo 8-os savaitès iki gimimo - vaisiumi.

33 Mačiulevičienè, R.; Jakušovaitè, I. Medicinos etikos problemos prenatalinèje diagnostikoje. Lietuvos akušerija ir ginekologija. 2008, 9(3): 219. 
jančio dokumento tekste (o visi jie yra ir Lietuvos teisinès sistemos dalis) nèra detalesnių nuostatų, nurodančių gyvybès apsaugos pradžios ir pabaigos momentą. Nors juose skelbiama, kad „Kiekvienas turi teisę ì gyvybę“ (Visuotinès žmogaus teisių deklaracijos ${ }^{34} 3$ str.), „Kiekvieno teisę ì gyvybę gina ịstatymas“ (Tarptautinio pilietinių ir politinių teisių pakto ${ }^{35} 6$ str. 1 dalis), „Kiekvieno asmens teisę ì gyvybę saugo įstatymas" (Europos žmogaus teisių ir pagrindinių laisvių konvencijos ${ }^{36} 2$ str.), sąvokos „kiekvienas“ turinys nèra patikslintas. Europos Žmogaus Teisių Teismas, turintis teisę interpretuoti prieš tai paminètąją Konvenciją ir Žmogaus teisių ir biomedicinos konvenciją, ị kurią irgi perkelta sąvoka „kiekvienas“, savo doktrinoje tradiciškai vengia išaiškinti, ar Europos žmogaus teisių ir laisvių konvencijos 2 str. nuostatos dèl kiekvieno asmens teisès i gyvybę yra taikomos ir dar negimusiam vaikui. Neaišku ir tai, kokia apimtimi taikytinas Jungtinių Tautų vaiko teisių konvencijoje įtvirtintas įsipareigojimas ginti vaiko teises tiek iki gimimo, tiek po jo ${ }^{37}$. Tai leidžia konstatuoti, kad tarptautinès teisès lygiu nesiryžtama aiškiau apibrèžti pradèto, bet dar negimusio vaiko teisinio statuso ir laikomasi pozicijos, kad „,kiekviena valstybė gali turéti savas nuostatas, kas yra gyvybės pradžia“"38. Toks neapibrěžtumas savu ruožtu atsispindi nacionalinèse teisès sistemose ir gresia silpniausių - dar negimusių visuomenès narių, teisių pažeidimu neetiškai taikant prenatalinės diagnostikos metodus ${ }^{39}$.

Lietuvoje, kaip ir daugelyje Europos šalių, dar negimusio vaiko teisinis statusas nèra aiškiai apibrèžtas. Nors, kaip minèta anksčiau, preimplantacinė diagnostika mūsų šalyje nèra teisiškai reglamentuota ir teoriškai negalima, abortas, ypač esant nepalankioms vaisiaus sveikatos indikacijoms, kaip reiškinys sulaukia didelio socialinio palaikymo, o teisine terpe ji praktikuoti labai palanki. Žmogaus gyvybès apsaugos prenatalineje fazeje problema Lietuvoje yra dviprasmiška. Iki šiol nẻra nacionalinių teisès aktų, apibrèžiančių žmogaus gyvybès iki gimimo statusą, nors keleto projektų, kuriais iš esmès siūloma pakeisti šiuo

34 Visuotinè žmogaus teisių deklaracija. Valstybès žinios. 2006, Nr. 68-2497.

35 Tarptautinis ekonominių, socialinių ir kultūrinių teisių paktas. Valstybès žinios. 2002, Nr. 77-3290.

36 Konvencija dèl žmogaus teisių ir orumo apsaugos biologijos ir medicinos taikymo srityje (Žmogaus teisių ir biomedicinos konvencija). Valstybès žinios. 2002, Nr. 97-4258.

37 Jungtinių Tautų vaiko teisių konvencija. Valstybès žinios. 1995, Nr. 60-1501.

38 Narbekovas, A.; Obelenienè, B.; Juškevičius, K., et al. Medicina, etika ir teisé apie žmogu iki gimimo. Mokslinè monografija.K aunas: VDU, 2012, p. 255.

39 Reikia pripažinti, kad, pavyzdžiui, Italijos teisinis reguliavimas, kuriuo draudžiama embrionų atranka prieš perkeliant ị gimdą, tačiau leidžiamas abortas remiantis medicininèmis indikacijomis, yra nenuoseklus. 2012 metų liepą byloje Costa and Pavan v. Italy Europos Žmogaus Teisių Teismas tai pastebejo ir taip pat nurodè, kad Italijos teisès aktai, užkirtę kelią taikyti preimplantacinę embriono diagnostiką cistinès fibrozès geno nešiotojų porai, yra nesuderinami su Europos žmogaus teisių konvencijos 8 straipsniu (teisè ị pagarbą asmeniniam ir šeimos gyvenimui). Costa and Pavan v. Italy [interaktyvus]. [žiūrèta 2014-08-06]. <http://hudoc.echr.coe.int/sites/eng/ pages/search.aspx?i=001-112993\#\{"itemid":["001-112993"]\}>. 
metu galiojančias nėštumo nutraukimo sąlygas ir tvarką reglamentuojančias teisès normas, esama ${ }^{40}$. Aborto atlikimo procedūrą šiuo metu reglamentuoja 1994 m. išleistas Lietuvos Respublikos sveikatos apsaugos ministerijos ịsakymas „Dèl nèštumo nutraukimo operacijos atlikimo tvarkos“ (pakeitęs TSRS sveikatos apsaugos ministerijos 19820316 d. įsakymą Nr. 234), nustatantis, jog moters pageidavimu leidžiama nutraukti néštumą iki 12 savaičių, jei nẻra šiai operacijai kontraindikacijų. Jei nustatyta vaisiaus patologija, kuri yra nesuderinama su gyvybe (vaisius vis viena mirs), priešlaikinio gimdymo sukèlimas galimas iki 22 něštumo savaitės. Tačiau šiame teisès akte nèra minima, kokiais aukštesnès galios teisès aktais Sveikatos apsaugos ministras remiasi, spręsdamas šio klausimo reglamentavimą. Šiame įsakyme pateiktas sąrašas ligų, grèsmingų néščios moters ir vaisiaus gyvybei bei sveikatai, parengtas vadovaujantis tarptautine ligu klasifikacija, kuri nebegalioja daugiau nei dešimtmetį ${ }^{41}$.

Lietuvoje mokslinių duomenų apie priežastis bei indikacijas, kuriomis vadovaujantis praktiškai pasirenkamas něštumo nutraukimas dẻl medicininių indikacijų nèra ${ }^{42}$. Literatūros duomenimis, „,patologinis nèštumas nutraukiamas daug dažniau nei išsaugomas ${ }^{\text {"433 }}$, todèl retų ligų ịtarimo ir diagnozès pateikimo atveju prenatalinę diagnostiką, U. Eibacho žodžiais, galima ịvardinti kaip „diagnostiką su mirtinais padariniais ${ }^{\text {(44 }}$. „Tai didelè etinė problema, nes kyla didelis pavojus, kad prognozè tampa prasminga tik tiek, kad gautų atsakymą ị klausimą, kiek mes - visuomené, gydytojai ar tèvai - ją toleruotume ${ }^{4_{45}}$, kadangi gydymo galimybių beveik nèra. Esant tokiai situacijai kyla pavojus, kad naujieji medicinos metodai, igalinantys diagnozuoti (nors ne visada absoliučiai tiksliai) tam tikrą genetinį sklaidos sutrikimą remiantis išvada, kad „yra rizika arba polinkis susirgti“", neleis gimti ligotoms gyvybèms ir kad neišvengiamai prastos sveikatos prognozès sukels vis daugiau abejonių dèl teisès gyventi negimusiems neigaliems ar lètinėmis ligomis sergantiems žmonèms. Todèl svarbu, kad šios srities valstybès politikoje prioritetu būtų laikomi gerovès ir pagarbos etiniai principai, o ne visuomenès ,spaudimo“ ir interesų tenkinimas. Pasak D. Serapino, „tikslai, dèl kurių prašoma atlikti prenatalinę diagnostiką ir dẻ kurių ji praktikuojama, turi visuomet būti palankūs vaikui ir jo motinai, nes jų kryptis yra leisti terapiškai įsikišti ir nuraminti néščias motinas, kankinamas abejonių dèl vaisiaus deforma-

40 Gyvybės prenatalinejje fazeje apsaugos ịstatymo projektai: $2013 \mathrm{~m}$. kovo $10 \mathrm{~d}$. Nr. XIIP-337; 2005 m. liepos 7 d. Nr. XP-432(2); 2005 m. balandžio 20 d. Nr. XP-432.

41 Supra note 38, p. 256-265.

42 Araminaite, V. Prenatalinè diagnostika: visuomenès sveikatos ir bioetikos aspektai. Visuomenès sveikata. 2011, 2(53): 32.

43 Ibid.

44 Eibach, U. Negimusių kūdikių diagnostika ir kančios ịveikimas. Prizmè. 2000, 3: 50-54. In Mačiulevičienè, R., Jakušovaite, I., supra note 31, p. 223.

45 ten Have, H. A. M. J.; ter Meulen, R. H. J.; van Leeuwen, E. Medicinos etika. Vilnius: Charibde, 2003. 
cijų ir gundomas nutraukti nèštumą, bei parengti jas priimti gyvybę, paženklintą negalia" ${ }^{{ }^{46}}$. Šiandiena pagal tarptautines rekomendacijas, jei nustatoma igimta anomalija, gydytojui draudžiama moteriai rekomenduoti abortą. Taigi genetinis konsultavimas turi būti ypač nedirektyvus ${ }^{47}$. „Siekiant išvengti piktnaudžiavimo, prenataliniai tyrimai turètų būti atliekami tik universitetiniuose medicinos centruose, esant griežtai medicininei priežiūrai, laikantis etikos normų “" ${ }^{48}$ „Tik šeima turi teisę spręsti negimusio kūdikio likimą: nespaudžiama priimti skubotų, subjektyvių sprendimų, nešališkai informuota apie diagnozę ir perspektyvą, nedramatizuojant faktų ir suteikiant visą reikalingą pagalbą priimti informuotą sprendimą ${ }^{\text {(49 }}$ Svarbu imtis politinių ir teisinių priemonių dèl psichologinès pagalbos teikimo šeimoms, nes šiuo metu, kaip rodo V. Araminaitės tyrimas, Lietuvoje pacientès yra visapusiškai informuojamos apie galimas pasirinkimo baigtis, tačiau, deja, psichologo paslaugos ir poabortinis psichologinis konsultavimas perinatologijos centruose nèra numatytas ${ }^{50}$.

\section{Sistemingos pagalbos retomis ligomis sergantiems pacientams teisinio reguliavimo ypatumai ir problemos}

\subsection{Asmens sveikatos priežiūros paslaugų sistema retomis ligomis sergantiems pacientams}

Retomis ligomis sergančių pacientų asmens sveikatos priežiūra turètų veikti kaip darni sistema: ịtarus retą ligą, pacientas turètų būti siunčiamas konsultuotis ị specializuotas paslaugas teikiančią asmens sveikatos priežiūros įstaigą; diagnozavus retą ligą, daugiadalykè sveikatos priežiūros specialistų komanda turètų suteikti reikiamas asmens sveikatos priežiūros paslaugas; vèliau turètų būti tęsiama paciento stebėsena ar slauga pacientui artimoje socialinèje aplinkoje, užtikrinamas grịžtamasis ryšys su specializuotas paslaugas teikiančia asmens sveikatos priežiūros įstaiga.

Šiuo metu problema ta, kad Lietuvoje skirtingų asmens sveikatos priežiūros lygių specialistų veiksmai kalbant apie retomis ligomis sergančių asmenų sveikatos priežiūrą yra nepakankamai suderinti. Kol kas daugumą paslaugų pacientams teikia arčiausiai jų gyvenamosios vietos pirminio bei antrinio lygmens paslaugas teikiančiose asmens sveikatos priežiūros įstaigose dirbantys specialis-

Serapinas, D. Prenatalinès diagnostikos medicininiai, etiniai ir teisiniai aspektai. Sveikatos mokslai. 2012, 22(3): 131-136.

47 Christopher, J. Maternal Serum Triple Analyte Screening in pregnancy. American Family Physician. 2002, 65(5): 915-921. In Serapinas, D, supra note 41, p. 136.

48 Supra note 38, p. 79.

$49 \quad$ Supra note 42, p. 29.

$50 \quad$ Ibid., p. 33. 
tai. Patirties ir specialių žinių stoka sunkina darbą, todèl yra poreikis, kad labai specializuota pagalba retomis ligomis sergantiems pacientams būtų centralizuojama. Europos Parlamento ir Tarybos 2011/24/ES direktyvoje pažymima, kad centralizuotai teikiant specializuotą sveikatos priežiūrą užtikrinama paslaugu kokybè ir aukšto lygio ekspertizè bei efektyviau naudojami ištekliai ${ }^{51}$. Panašiomis idejjomis dalijasi ir A. Utkus, teigdamas, kad ekspertinių sistemų taikymas diagnozuojant retąsias ligas yra svarbus veiksnys, palengvinantis specialisto darbą, o tiksliai diagnozei nustatyti svarbūs žmogiškieji ištekliai ir infrastruktūra ${ }^{52}$.

Lietuvoje pastaraisiais metais daugiaprofilèse universitetų ligoninėse pradèti steigti retų ligų „,centriukai“ (cistinès fibrozės; plautinès hipertenzijos ir kt.). Ivertinus pacientų srautus, personalo patirti, diagnostikos ir gydymo galimybes, mokymo, mokslo patirtị, užmegztus tarptautinius ryšius 2012 m. rugsẻjo ménesị Vilniaus universiteto Santariškių klinikose buvo ịkurtas pirmasis Lietuvoje Vaikų retų ligų koordinavimo centras, $2013 \mathrm{~m}$. veiklą pradejo Lietuvos sveikatos mokslų universiteto Kauno klinikų Retų ligų koordinacinis centras. Šiuo metu čia veikia 10 retųjų ligų centrų, kurių tikslas - užtikrinti daugiaprofilę specializuotą pagalbą retomis ligomis sergantiems pacientams. Vis dèlto retų ligų centrų kūrimo iniciatyva (nors iš pirmo žvilgsnio labai patraukli ir palanki pacientams) atitinkamų specializacijų gydytojų bei suinteresuotų sveikatos priežiūros įstaigų administracijos Lietuvoje sutinkama ne itin palankiai. Pavyzdžiui, siekis Kauno klinikose ịkurti vienintelị Lietuvoje Retų neurochirurgijos ligų centrą ${ }^{53}$ sulaukè kritikos dèl galimų prieštaravimų Konstitucijos 46 straipsniui (sąžininga sveikatos priežiūros įstaigų konkurencija) ir Pacientų teisių ir žalos sveikatai atlyginimo i̇statymo 4 straipsnyje įtvirtintai paciento teisei pasirinkti sveikatos priežiūros įstaigą ${ }^{54}$. Šis pavyzdys rodo, kad igyvendinant ES rekomendacijas dèl retų ligų centrų kūrimo pirmiausia būtina pasiekti sutarimą tarp visų suinteresuotų sveikatos priežiūros įstaigų, medikų asociacijų ir sveikatos sistemos politiką formuojančių ir igyvendinančių institucijų. Be to, iš esmès keičiant galiojančią tvarką, naujos teisès aktų nuostatos turètų ịsigalioti palaipsniui, kad būtų išvengta neigiamų pasekmių. Taigi, ar retų ligų centrai neliks tik formalūs, priklausys ir nuo jų finansavimo, Lietuvos didžiųjų miestų sveikatos priežiūros įstaigų konkurencijos ir tarpusavio bendradarbiavimo bei kitų ypatumų. Planuojant retomis ligomis sergančių pacientų asmens sveikatos priežiūrą, lèšas

51 Europos Parlamento ir Tarybos 2011 m. kovo 9 d. direktyva 2011/24/ES „Dèl pacientų teisių i tarpvalstybines sveikatos priežiūros paslaugas igyvendinimo“. [2011] OL L 88/45.

$52 \quad$ Supra note 19, p. 41.

53 Lietuvos Respublikos sveikatos apsaugos ministro 2014 m. birželio 10 d. ịsakymas Nr. V-677 „Dèl Neurochirurgijos paslaugų optimizavimo 2014-2020 metų plano patvirtinimo“. Valstybès žinios. 2014, Nr. 2014-07605.

54 Lietuvos Respublikos SeimoSveikatos reikalų komiteto 2014 m. liepos 16 d. sprendimas „Dèl neurochirurgijos paslaugų organizavimo"[interaktyvus]. [žiūrèta 2014-08-25]. <www3.lrs.lt/ docs2/HPIVCRZP.DOCX>. 
profilaktikai ir gydymui, būtina nacionaliniu mastu vykdyti retųjų ligų stebėseną, taip pat reiketų persvarstyti šiuo metu veikiančią retomis ligomis sergantiems pacientams suteiktų asmens sveikatos priežiūros paslaugų išlaidų apmokejjimo sistemą.

\subsection{Retomis ligomis sergančių pacientų siuntimo gydytis ị užsienị tvarka}

Remiantis šiuo metu galiojančia Pacientų siuntimo konsultuotis, išsitirti ir (ar) gydytis Europos ekonominei erdvei priklausančiose valstybėse ir Šveicarijoje tvarka, pacientai gali gauti paslaugas užsienio klinikose, ,,jei Lietuvoje atitinkamos ar tokios pat veiksmingos konsultavimo, ištyrimo ir (ar) gydymo paslaugos, teikiamos PSDF biudžeto lèšomis, dèl šių asmenų sveikatos būklès ir numanomos ligos eigos negali būti jiems suteiktos per mediciniškai pateisinamą laiką " ${ }^{55}$. Anksčiau šiame teisės akte galiojo Europos Teisingumo Teismo praktikos neatitinkanti sąlyga, kad paslaugas užsienyje pacientai gali gauti ,jei visi Lietuvoje galimi tyrimo ir gydymo metodai neduoda rezultatų ${ }^{{ }^{56} 6}$. Leidimus gauti medicinos paslaugas kitoje valstybeje Lietuvoje išduoda Valstybinè ligonių kasa. Sprendimą dèl konsultavimo, ištyrimo ir (ar) gydymo užsienyje priima sveikatos apsaugos ministro ịsakymu sudaryta komisija. Sprendimą dèl būtinybès vykti ị užsieni priima universitetinių gydymo ịstaigų gydytojai, pas kuriuos konsultuotis nustatyta tvarka ligonius siunčia gydantis gydytojas. Specialistai ne tik įvertina tokių pacientų sveikatos būklę, bet ir „pacientų individualius medicininius poreikius, ligos eigą bei tikètinus padarinius“. „Paciento kelionès ir pragyvenimo išlaidos bei sumokètos priemokos ir mokesčiai nekompensuojami “"57. Kad retomis ligomis sergantys pacientai būtų ištirti svetur, Lietuva per metus atseikèja iki 1,5 $\mathrm{mln}$. litų. Gydytis kitose šalyse kasmet išsiunčiama $40-50$ pacientų.

Nuo 2013-ųjų metų Lietuva privalo igyvendinti 2011/24/ES direktyvą dèl pacientų teisių $\mathfrak{i}$ tarpvalstybines sveikatos priežiūros paslaugas ${ }^{58}$. Direktyvos 8 straipsnio 4 dalyje numatyta, kad pacientas, kuris serga reta liga ar kurio atveju ịtariama, kad jis serga reta liga, gali pasinaudoti išorés ekspertų žiniomis ligai diagnozuoti ir kad turètų būti suteiktas išankstinis leidimas jiems teikti sveikatos priežiūros paslaugas kitose valstybėse narèse, jei tai neįmanoma draudimo

55 Lietuvos Respublikos sveikatos apsaugos ministro 2013 m. liepos 23 d. ịsakymas Nr. V-724 „Dèl Lietuvos Respublikos sveikatos apsaugos ministro 2010 m. rugpjūčio 16 d. ịsakymo Nr. V-729 „Dèl Pacientų siuntimo konsultuotis, išsitirti ir (ar) gydytis Europos ekonominei erdvei priklausančiose valstybèse ir Šveicarijoje tvarkos aprašo patvirtinimo" pakeitimo“. Valstybės žinios. 2013, Nr. 824099 .

56 Lietuvos Respublikos sveikatos apsaugos ministro 2010 m. rugpjūčio 16 d. įsakymas Nr. V-729 „Dèl pacientų siuntimo konsultuotis, išsitirti ir gydytis Europos ekonominei erdvei priklausančiose valstybėse ir Šveicarijoje tvarkos aprašo patvirtinimo“. Valstybès žinios. 2010, Nr. 99-5162.

57 Supra note 55, 17 punktas.

58 Supra note 51. 
valstybejje narejje. Tuo tikslu steigiami ir plètojami Europos referencijos centru tinklai, sutelkiant daug išteklių ir žinių retų ligų diagnostikai ir gydymui.

Šiuo metu Lietuvoje galiojantys teisès aktai specialių nuostatų ar išimčių dèl išankstinių leidimų suteikimo retomis ligomis sergantiems pacientams nenumato. Taikomos bendros taisyklès kaip ir kitiems pacientams, todèl ateitis parodys, ar tai netaps kliūtimi. Nacionaliniame retų ligų plane numatyta Lietuvoje plačiau naudoti telemedicinos galimybes, konsultuojantis su užsienio specialistais ${ }^{59}$.

\subsection{Retųjų vaistų tiekimo teisinis reguliavimas, prieinamumo pacientams problemos ir jų teisinis vertinimas}

Retoms ligoms gydyti skirtų vaistų pasiūla rinkoje dèl ES inicijuotos paskatų sistemos jų kūrẻjams per daugiau nei dešimtmetị gerokai ūgtelèjo. Iki 2013 metu pabaigos net 88 retiesiems vaistams suteikti rinkodaros leidimai ${ }^{60}$. Retieji vaistiniai preparatai, kaip ir kiti vaistiniai preparatai, platinami bei išduodami (parduodami) gyventojams vadovaujantis Lietuvos Respublikos farmacijos įstatymo $^{61}$ ir jo lydimųjų teisès aktų nuostatomis. Bendra taisyklè, kad Lietuvos rinkai tiekiami ịregistruoti vaistai ${ }^{62}$, šių preparatų tiekimui užtikrinti Lietuvoje gali būti taikoma ir lygiagretaus platinimo procedūra ${ }^{63}$. Tačiau retomis ligomis sergančius pacientus gali pasiekti ir šalyje neregistruoti vaistiniai preparatai, nes teisinès išimtys yra taikomos būtiniesiems ir vardiniams vaistiniams preparatams. Vardinių vaistinių preparatų taisyklių ${ }^{64} 9$ bei 10 punktuose iš esmès pakartotas 2001/83/EB direktyvos 5 straipsnis, nurodant, kad jei nèra galimybių Lietuvoje registruotais vaistais gydyti pacientą, diagnozuoti ligą ar jos išvengti, o gydymo neregistruotu vaistu naudos ir rizikos santykis yra reikšmingai palankesnis negu šalies rinkoje esamų vaistinių preparatų ir gydymo būdų (10 punktas), toks vaistas gali būti tiekiamas ị Lietuvos Respubliką remiantis to paciento gydytojo paskyrimu ir skirtas vartoti tiesiogiai šiam gydytojui atsakant. Atkreiptinas demesys, kad Lietuvoje perkeliant 2001/83/EB direktyvos 5 straipsni pasirinkta

59 Supra note 5.

60 Orphanet Report Series - Lists of medicinal products for rare diseases in Europe. October 2013, p. 37 [interaktyvus]. [žiūrèta 2014-08-07]. <http://www.orpha.net/orphacom/cahiers/docs/GB/ list_of_orphan_drugs_in_europe.pdf $>$.

${ }_{61}$ Lietuvos Respublikos farmacijos įstatymas. Valstybès žinios. 2006, Nr. 78-3056.

62 Lietuvos Respublikos vaistinių preparatų registre, Bendrijos vaistinių preparatų registre arba Lygiagrečiai importuojamų vaistinių preparatų sąraše (Lietuvos Respublikos farmacijos ịstatymo 8 straipsnio 1 dalis).

63 Reikia vadovautis Europos Tarybos reglamento (EB) Nr. 726/2004 nuostatomis. Tuo tikslu didmeninis platintojas turi teikti Europos vaistų agentūrai paraišką ir dokumentus, kad igytų teisę tokius vaistinius preparatus platinti lygiagrečiai.

64 Vardinių vaistinių preparatų ịsigijimo tvarką reglamentuoja „Vardinių vaistinių preparatų ísigijimo taisyklès“, patvirtintos Lietuvos Respublikos sveikatos apsaugos ministro $2005 \mathrm{~m}$. gegužès 9 d. įsakymu Nr. V-374 (Valstybés žinios. 2005, Nr. 61-2189; 2007, Nr. 42-1598). 
pati siauriausia jo interpretacija - apsiribota tik šalyje neregistruotų vaistų prieinamumu pavieniams pacientams, tačiau neitteisintas paskutinèje priešregistracinejje (arba, kitaip tariant, 3-iojoje) klinikinių tyrimų fazèje esančių vaistų prieinamumas. Lietuvos teisès aktuose teisiškai nereglamentuotas ir vadinamųjų „,vilties vaistų ${ }^{\text {“65 }}$ vartojimas retų ligų atvejais pacientų grupèms. Nepaisant to, jog Europos vaistų agentūra dar 2007 m. liepą yra išleidusi gaires ${ }^{66}$, palengvinančias 726/2004/EB reglamento 83 straipsnio supratimą ir igyvendinimą, ị nacionalinę teisę ši nuostata iki šiol néra perkelta. Tuo tarpu ị vardinių preparatų kategoriją patenka tik itin nežymi dalis apskritai neregistruotų vaistinių preparatų, kurie paprastai patenka $\mathfrak{i}$ „,vilties" preparatų kategoriją. Dèl šių apribojimų teritorinis retųjų vaistų prieinamumas mūsų šalies pacientams vertintinas kaip problemiškas, užtikrintas nepakankamai.

Dar aštriau mūsų šalies pacientai patiria ekonominio retųjų vaistų prieinamumo problemą, kurios lemiamas faktorius labai didelè jų kaina. Vaistų retomis ligomis sergantiems pacientams kompensavimas yra nemažas iššūkis net ir turtingoms šalims. Todèl Lietuvos teisès aktuose, nustatančiuose šių vaistų kompensavimo tvarką, nurodoma, kad sveikatos priežiūros paslaugų išlaidos ir labai retoms ligoms, kurios apibrèžtos kaip „pavieniai ypatingi ligos ar būklès atvejai“, gydyti reikiamų vaistų bei medicinos pagalbos priemonių ịsigijimo išlaidos kompensuojamos iš PSDF biudžeto, ,,neviršijant einamaisiais metais patvirtintų rodiklių“. Lietuvoje retų ligų ir būklių atvejais nustatyta individuali vaistų kompensavimo tvarka, kai kiekvienu konkrečiu atveju sprendimą priima specialistų komisijos ${ }^{67}$. 2008-2011 metais iš PSDF biudžeto skirtos lešos retoms ligoms gydyti iš centralizuotiems pirkimams skirtų lěšų buvo tokios: 2008 metais bendros PSDF biudžeto išlaidos retoms ligoms gydyti buvo 9,1 mln. litų, 2009 - 10,2, 2010 - 10,6, 2011 - 16,2 mln. litų. Pacientų skaičius 2011 lyginant su 2008 metais beveik padvigubèjo - nuo 283 iki 542, taigi vidutinès išlaidos vienam pacientui sumažejjo - 2008 metais vienam pacientui vidutiniškai teko 32,1 tūkst. litų, o 2011 - 29,9 tūkst. litų. Atsižvelgiant ị šiuos duomenis, tenka konstatuoti, kad PSDF biudžeto lèšų, skirtų centralizuotai perkamiems vaistams retoms ligoms ir būklèms gydyti, nepakanka visų pacientų gydymo reikmėms patenkinti. Ar valstybė nepažeidžia šių pacientų teisių sveikatos priežiūros srityje? - teisinio vertinimo reikalaujanti problema.

\footnotetext{
65 „Vilties vaistiniais preparatais“ (angl. compassionate use medicinal products) vadinami neregistruoti vaistiniai preparatai, atitinkantys Reglamento (EB) Nr. 726/2004 83 straipsnio nuostatas.

66 Guideline on compassionate use of medicinal products, pursuant to article 83 of regulation (EC) No 726/20004. London: EMEA, 19 July 2007.

67 Valstybinès ligonių kasos prie Sveikatos apsaugos ministerijos direktoriaus $2005 \mathrm{~m}$. lapkričio 22 d. ịsakymas Nr. 1K-149 „Dèl Sprendimų dèl vaistų ir medicinos pagalbos priemonių labai retoms ligoms ir būklèms gydyti kompensavimo ir dèl nenumatytų atvejų prièmimo komisijos darbo reglamento patvirtinimo“. Valstybès žinios. 2005, Nr. 139-5037.
} 
Europos Parlamento ir Tarybos reglamente 141/2000 „Dèl retųjų vaistų” nurodoma, kad „(r)etomis ligomis sergantys ligoniai turètų turèti teisę gauti tokios pat kokybės gydymą kaip ir kiti ligoniai" ${ }^{\text {"68. }}$. Žmogaus teisių ir biomedicinos konvencijos 3 straipsnis nurodo, kad ,„(̌) alys, atsižvelgdamos į sveikatingumo reikmes ir turimus išteklius, imasi atitinkamu priemoniu, kad savo jurisdikcijoje sudarytų lygiateisiškas galimybes gauti atitinkamos kokybės sveikatos priežiūrą" "69, o 2006 metų Jungtinių Tautų neigaliųjų teisių konvencijos 25 straipsnis nurodo, kad „Valstybès, šios Konvencijos Šalys, pripažista, kad neịgalieji turi teisę i aukščiausią įmanomą sveikatos lygị jų nediskriminuojant dẻl neigalumo “70. Teisè $\mathfrak{i}$ sveikatos priežiūrą, teisè ị gyvybę, neigaliųjų diskriminacijos draudimas, lygybės ir solidarumo principai, kurie yra svarbūs užtikrinant visų pacientų, taip pat ir sergančių retomis ligomis, teises, yra įtvirtinti Lietuvos Konstitucijoje, šalyje galiojančiuose tarptautiniuose žmogaus teisių dokumentuose ${ }^{71}$ ir sveikatinimo veiklą reguliuojančiuose teisès aktuose. Vis dèlto prieš ketverius metus apgintoje disertacijoje kaip pagrindiniai veiksniai, kurie, tikètina, apsunkintų reta liga sergančio paciento pažeistų lūkesčių dèl brangių vaistų prieinamumo (kompensavimo) gynimą teisme, nurodyti šie: a) doktrinoje menkai išplètota teisès ị sveikatos priežiūrą bei jos prieinamumą koncepcija; b) neaiški šios teisès subjektinio ir teisnumo lygmenų skirtis; c) mėginimas eliminuoti teisę ị sveikatos priežiūros prieinamumą iš pacientų teisių katalogo; d) „vaistų prieinamumo“ definicijos teisinis neapibrèžtumas; e) PSDF biudžeto apimtis bei ribos; f) konstitucinėje doktrinoje plačiau nereflektuotas solidarumo principo turinys ${ }^{72}$.

Šiuo metu kai kurios iš išvardintų teisinių aplinkybių yra pasikeitusios: 2013 metais Konstitucinis Teismas pripažino, kad teisé ị sveikatos priežiūrą yra ne tik programine, bet ir individualaus pobūdžio asmens teisé $\dot{e}^{73}$; aiškindamas nemokamos medicinos pagalbos piliečiams teikimo ịsipareigojimą Konstitucinis Teismas nurodè, kad „,nemokama medicinos pagalba visiems piliečiams privalo būti užtikrinta tokia apimtimi, kokia ji yra būtina žmogaus gyvybei gelbèti ir išsaugoti" "4; solidarumo principo teisinè galia iš esmès buvo konkretizuota instrumentiniu valstybės įsipareigojimu ir visuomenés ịpareigojimu - t. y. atitinka-

68 Supra note 1.

69 Supra note 36.

70 Jungtinių Tautų neigaliujų teisių konvencija ir jos Fakultatyvus protokolas. Valstybès žinios. 2010, Nr. 71-3561. Nemaža dalis retomis ligomis sergančių pacientų, atsižvelgiant ị Konvencijoje pateiktą apibrèžimą, patektų ị neiggaliụjų asmenų kategoriją (aut. past.).

71 Tarptautinis ekonominių, socialinių ir kultūrinių teisių paktas. Valstybès žinios. 2002, Nr. 77-3290; Europos socialinè chartija (pataisyta). Valstybès žinios. 2001, Nr. 49-1704.

72 Špokiene, I. Retųjų vaistų prieinamumo reglamentavimas sveikatos teiseje, supra note 4, p. 168.

73 Lietuvos Respublikos Konstitucinio Teismo 2013 m. gegužè 16 d. nutarimas byloje Nr. 47/2009$131 / 2010$ „Dèl pareigos moketi valstybinio socialinio draudimo ir privalomojo sveikatos draudimo ịmokas, taip pat dèl motinystès (tèvystès) pašalpų sumažinimo" [interaktyvus]. [žiūrèta 2014-08-05]. <http://www.lrkt.lt/dokumentai/2013/n130516.doc>.

74 Ibid. 
mai valstybės pareiga kurti privalomojo sveikatos draudimo sistemą, o visuomenès narių pareiga mokèti jo įmokas. Pletodamas solidarumo principo turinị Teismas nurodé, kad „,valstybès pareiga sukurti visuomenès solidarumu pagrịstą sveikatos priežiūros finansavimo viešosiomis lèšomis sistemą, kuri leistų užtikrinti pakankamą sveikatos priežiūros prieinamumą, negali būti aiškinama taip, esą visuomenè turi prisiimti visu įmanomų asmens sveikatos priežiūros paslaugų finansavimo naštą “75. Taip pat pabrèžta, kad pakankamas prieinamumas anaiptol nereiškia, kad visuomenè turi prisiimti visų ịmanomų paslaugų finansavimą, nes tokie įsipareigojimai visų pirma priklauso nuo esamų išteklių. Atsižvelgiant ị tokia kryptimi plètojamą teisès ị sveikatos priežiūrą ígyvendinimo doktriną, tikètina, kad dèl lešsc trūkumo kriterijaus sprendimas pacientui nekompensuoti labai brangių vaistų gali būti teismo ịvertintas ir kaip teisètas paciento teisès ì sveikatos priežiūrą, jo prigimtinès teisés ị kuo geresnę sveikatą apribojimas. Vis dèlto etiniu požiūriu, kai dẻl finansavimo priežasčių pacientams siūlomi ne veiksmingi vaistai, o slauga, yra sunkiai pateisinama. Lygiai taip pat ir tie atvejai, kai vaistai neprieinami mūsų šalies pacientams (Valstybinès ligonių kasos komisijai ir Sveikatos apsaugos ministerijai atlikus jų pakartotinị vertinimą ir ivvertinus juos kaip nepakankamai saugius bei veiksmingus) yra kompensuojami tomis pačiomis ligomis sergantiems pacientams kaimyninèse šalyse ${ }^{76}$.

Todèl reikia sutikti su A. Natzu, kad ,būtina gerinti retųjų vaistų prieinamumą pacientams, peržiūrint ar suvienodinant kriterijus, kuriais remdamosi šalies sveikatos priežiūrą administruojančios institucijos sprendžia, ar vaistai turètų būti kompensuoti, ar ne ${ }^{77}$. Dèl Bendrijos kompetencijos žmogaus teisių srityje

75 Ibid.

76 Abejotina ar valstybe turètų skirti milžiniškas lëšas rizikingiems vaistams kompensuoti. Sveikatos apsaugos ministerija [interaktyvus]. 2012-06-08 [žiūrèta 2014-06-07]. <http://www.sam.lt/ popup2.php?ru=bS9tX2FydGljbGUvZmlsZXMvd19hcnRpY2xlX3ByaW50LnBocA==\&tm pl_name=m_article_print_view\&article_id=2952>; Jablonskaitè, D. Milijonas ar vaiko gyvybé? Sveikatos apsaugos sistema renkasi, ka gydyti, o ka pasmerkti [interaktyvus]. 2013-01-24 [žiūrèta 2014-06-07]. <http://www.15min.lt/naujiena/ziniosgyvai/sveikata/milijonas-ar-vaiko-gyvybesveikatos-apsaugos-sistema-renkasi-ka-gydyti-o-ka-pasmerkti-541-298039\#ixzz39XA19jmP>.

77 Natz, A. Putting a value on drugs for rare diseases. MedNous. September 2012, p. 8-9. <http:// www.natz-law.com/en/wp-content/uploads/sites/3/2013/04/EU-Orphan-drug-policy-NatzCampion1.pdf>.

2012 m. kovo 1 d. Europos Komisijos pateiktas pasiūlymas peržiūrèti 89/105/EEB direktyvą, be kita ko, ịterpiant nuostatą, kad „priimdamos sprendimus dẻl kainų nustatymo ir kompensavimo, šalių kompetentingos institucijos neturètų iš naujo vertinti pagrindinių aspektų, kuriais buvo remiamasi suteikiant rinkodaros leidimą, įskaitant vaisto kokybę, saugą, veiksmingumą, bioekvivalentiškumą arba biologinị panašumą. Retụjų vaistų atveju kompetentingos institucijos neturètų iš naujo vertinti priskyrimo prie retujų vaistų kategorijos kriterijų. Tačiau kompetentingoms institucijoms įtraukiant vaistą ị valstybinę sveikatos draudimo sistemą, turètų būti suteikta galimybẻ susipažinti su visais duomenimis, kuriuos naudoja už vaistų rinkodaros leidimų išdavimą atsakingos institucijos, taip pat galimybe įterpti ar surinkti papildomų duomenų, tinkamų vaistams vertinti“. Jei šiam pasiūlymui būtų pritarta retụjų vaistų prieinamumas pacientams turètų pagerèti. Tačiau svarstant minètą pasiūlymą Lietuvoje bei kitose šalyse buvo suabejota, ar šiais pakeitimais nebūtų pažeidžiamas subsidiarumo principas. 
ribotumo ir igaliojimų asmens sveikatos priežiūros srityje apribojimų ES teisès ịtaka užtikrinant ekonominị vaistų prieinamumą yra nedidelè. Savu ruožtu pačios valstybès, tarp jų ir Lietuva, turi dèti visas įmanomas pastangas (skirti lèšų; taikyti sąžiningą ir racionalų vaistų efektyvumo ir terapinès vertès vertinimą), kad retomis ligomis sergantys pacientai gautų jų sveikatos reikmes ir mokslinès pažangos standartus atitinkantị gydymą. ,Jei buvo rastas būdas skatinti investicijas ị šių vaistų kūrimą, reikètų užtikrinti, kad vaistai būtų prieinami pacientams. ${ }^{\text {"78 }}$

\section{Išvados ir pasiūlymai}

1. Retų ligų prevencijos politikos kryptis Lietuvoje igyvendinama visuotinio naujagimių tikrinimo ir genetinio konsultavimo priemonemis.

1.1. Visuotinis naujagimių tikrinimas dèl igimtos hipotirozès ir fenilketonurijos pasižymi universalumu, taikomas visai tikslinei populiacijai, igyvendinamas sèkmingai.

1.2. Preimplantacinès diagnostikos metodas Lietuvoje teisiškai nereglamentuotas, tačiau ịdiegtas griežtas embriono apsaugos atliekant biomedicininius tyrimus teisinis režimas leidžia daryti įžvalgą dèl atsargios Lietuvos politinès pozicijos šio metodo taikymo atžvilgiu.

1.3. Prenatalinès diagnostikos taikymas ir néččiosioms siūlomos ,išeitys" retos ligos diagnozės atveju kelia tam tikrų teisinių prieštaravimų: nẻra nacionalinių teisės aktų, apibrěžiančiu žmogaus gyvybès iki gimimo (negimusio vaiko) teisinį statusą; nèra „aborto” ar „nèštumo nutraukimo“ apibrěžimų; žmogaus gyvybès prenatalinėje stadijoje nutraukimas įtvirtinamas įstatymo igyvendinamojo teisès akto rangą turinčiu ministro įsakymu. Šie trūkumai turi būti ištaisyti priimant Gyvybès prenatalinėje stadijoje apsaugos įstatymą. Etiniai prieštaravimai: atrankinių nèštumo nutraukimų taikymas vaisiams, galintiems gimti su negale; diagnozuota ir neišgydoma dar negimusio vaiko reta liga siūlant aborto išeitị neišvengiamai kvestionuoja jo gyvenimo vertę. Genetinis konsultavimas privalo būti nedirektyvus, tikslai, dèl kurių prašoma atlikti prenatalinę diagnostiką ir dèl kurių ji praktikuojama, turi visuomet būti palankūs vaikui ir jo motinai, ji turi būti naudojama tik individualios šeimos, o ne visuomenès interesams patenkinti, lydimas psichologo konsultacijų.

2. Sisteminga pagalba sergantiesiems (asmens sveikatos priežiūros paslaugų sistema; siuntimas konsultuotis ir gydytis į užsienį; vaistų prieinamumas) yra antra pagrindiné nacionalinès politikos retų ligų srityje kryptis.

2.1. Asmens sveikatos priežiūros paslaugų, teikiamų retomis ligomis sergantiems pacientams, sistemai kol kas stinga organizuotumo. Teigiami 
pokyčiai: retų ligų specializuotų centrų kūrimasis. Siekiant pagerinti situaciją reikètų persvarstyti šiuo metu veikiančią retomis ligomis sergantiems pacientams suteikiamų asmens sveikatos priežiūros paslaugų išlaidų apmokẻjimo sistemą, būtina nacionaliniu mastu vykdyti retų ligų stebėseną, telkti infrastruktūrą ir žmogiškuosius resursus, spręsti SPI konkurencijos kuriant retų ligų centrus problemas.

2.2. Šiuo metu galiojantys teisès aktai, kuriais remiantis retomis ligomis sergantys pacientai gali vykti konsultuotis, išsitirti ir (ar) gydytis ị užsienị, atitinka ES teisès nuostatas dèl tarpvalstybinių sveikatos priežiūros paslaugų teikimo. Pagal nacionalinę teisę šios grupès pacientams atskiros nuostatos ar išimtys dèl leidimų išdavimo nèra taikomos.

2.3. Dabartinis vaistų retoms ligoms gydyti prieinamumo teisinis reglamentavimas sudaro sąlygas tiekti retuosius vaistus Lietuvos rinkai. Esminis trūkumas, kad dar nèra įteisintas vadinamųjų ,,vilties vaistinių preparatų" naudojimas. Etinės problemos: nepakankamas retųjų vaistų kompensavimas; pakartotinis vaistų efektyvumo ir terapinès vertės vertinimas.

\section{Literatūra}

1. Araminaitè, V. Prenatalinè diagnostika: visuomenès sveikatos ir bioetikos aspektai. Visuomenés sveikata. 2011, 2(53): 29-35.

2. Burgard, P.; Cornel, M.; Di Filippo F.; Haege, G., and etc. EU tender "Evaluation of population newborn screening practices for rare disorders in Member States of the European Union". Short Executive Summary of the Report on the practices of newborn screening for rare disorders implemented in Member States of the European Union, Candidate, Potential Candidate and EFTA Countries [interaktyvus]. 2012 [žiūrèta 2014-08-06] <http://ec.europa.eu/eahc/documents/news/Summary_20120110.pdf>.

3. Christopher, J. Maternal Serum Triple Analyte Screening in pregnancy. American Family Physician. 2002, 65(5): 915-921.

4. Costa and Pavan v. Italy [interaktyvus]. [žiūrèta 2014-08-06]. <http://hudoc.echr.coe. int/sites/eng/pages/search.aspx?i=001-112993\#\{“itemid”:[“001-112993”]\}>.

5. Council Recommendation of 8 June 2009 on an action in the field of rare diseases. [2009] OJ C 151/2.

6. Eibach, U. Negimusių kūdikių diagnostika ir kančios įveikimas. Prizmė. 2000, 3: 50-54.

7. Europos Parlamento ir Tarybos 1999 m. gruodžio 16 d. reglamentas Nr. 141/2000 „Dèl retųjų vaistų“. [2000] OL L 18/1.

8. Europos Parlamento ir Tarybos $2011 \mathrm{~m}$. kovo 9 d. direktyva 2011/24/ES „Dèl pacientų teisių ị tarpvalstybines sveikatos priežiūros paslaugas iggyvendinimo“. [2011] OL L $88 / 45$.

9. Gyvybès prenatalinèje fazèje apsaugos ístatymo projektai: $2013 \mathrm{~m}$. kovo $10 \mathrm{~d}$. Nr. XIIP-337; 2005 m. liepos 7 d. Nr. XP-432(2); 2005 m. balandžio 20 d. Nr. XP-432.

10. Guideline on compassionate use of medicinal products, pursuant to article 83 of regulation (EC) No 726/20004. London: EMEA, 19 July 2007. 
11. Isasi, R. M.; Knoppers B. M. Regulatory approaches to reproductive genetic testing. Human Reproduction. 2004, 19(12): 2695-2701.

12. Jablonskaite, D. Milijonas ar vaiko gyvybè? Sveikatos apsaugos sistema renkasi, ka gydyti, o kq pasmerkti [interaktyvus]. 2013-01-24 [žiūrèta 2014-06-07] <http:// www.15min.lt/naujiena/ziniosgyvai/sveikata/milijonas-ar-vaiko-gyvybe-sveikatosapsaugos-sistema-renkasi-ka-gydyti-o-ka-pasmerkti-541-298039\#ixzz39XA19jmP >.

13. Jungtinių Tautų vaiko teisių konvencija. Valstybės žinios. 1995, Nr. 60-1501.

14. Jungtinių Tautų neigaliųjų teisių konvencija ir jos Fakultatyvus protokolas. Valstybés žinios. 2010, Nr. 71-3561.

15. Konvencija dèl žmogaus teisių ir orumo apsaugos biologijos ir medicinos taikymo srityje (Žmogaus teisių ir biomedicinos konvencija). Valstybés žinios. 2002, Nr. 97-4258.

16. Krajnovic, D. Ethical and social aspects of rare diseases. Filozofija/Društvo. 2012, XXIII (4): 32-48.

17. Lietuvos Respublikos baudžiamasis kodeksas. Valstybės žinios. 2000, Nr. 89-2741.

18. Lietuvos Respublikos biomedicininių tyrimų istatymas. Valstybès žinios. 2000, Nr. 44-1247.

19. Lietuvos Respublikos farmacijos ịstatymas. Valstybès žinios. 2006, Nr. 78-3056.

20. Lietuvos Respublikos Konstitucinio Teismo 2013 m. gegužès 16 d. nutarimas byloje Nr. 47/2009-131/2010 „Dèl pareigos mokèti valstybinio socialinio draudimo ir privalomojo sveikatos draudimo imokas, taip pat dèl motinystès (tévystès) pašalpų sumažinimo“ [interaktyvus]. [žiūrèta: 2014-08-05]. <http://www.lrkt.lt/ dokumentai/2013/n130516.doc $>$.

21. Lietuvos Respublikos sveikatos apsaugos ministro $2000 \mathrm{~m}$. spalio $6 \mathrm{~d}$. įsakymas Nr. 529 „Dèl Medicinos pagalbos priemonių sąrašo patvirtinimo“. Valstybės žinios. 2000, Nr. 85-2609; 2009, Nr. 141-6237.

22. Lietuvos Respublikos sveikatos apsaugos ministro $2003 \mathrm{~m}$. balandžio $14 \mathrm{~d}$. ịsakymas Nr. V-220 „Dèl Lietuvos medicinos normos MN 56:2003 „Gydytojas genetikas. Teisès, pareigos, kompetencija ir atsakomybë“ patvirtinimo“. Valstybès žinios. 2003, Nr. 43-1983.

23. Lietuvos Respublikos sveikatos apsaugos ministro $2007 \mathrm{~m}$. balandžio $5 \mathrm{~d}$. ịsakymas Nr. V-233 „Dèl Lietuvos Respublikos sveikatos apsaugos ministro 2005 m. gegužès 9 d. îsakymo Nr. V-374 „Dèl Vardinių vaistinių preparatų îsigijimo taisyklių patvirtinimo“" pakeitimo“. Valstybès žinios. 2007, Nr. 42-1598.

24. Lietuvos Respublikos sveikatos apsaugos ministro 2005 m. birželio 23 d. ịsakymas Nr. V-522 „Dèl Žmogaus genetikos paslaugų, apmokamų iš Privalomojo sveikatos draudimo fondo biudžeto, sąrašo ir jų bazinių kainų patvirtinimo“. Valstybès žinios. 2005, Nr. 90-3380.

25. Lietuvos Respublikos sveikatos apsaugos ministro $2008 \mathrm{~m}$. sausio $17 \mathrm{~d}$. ịsakymas Nr. V-49 „Dẻl Imunotipavimo, genetinio, kraujo krešejimo veiksnių tyrimų, apmokamų iš Privalomojo sveikatos draudimo fondo biudžeto, atlikimo reikalavimų ir apmokejjimo sąlygų aprašo patvirtinimo“. Valstybės žinios. 2008, Nr. 12-406.

26. Lietuvos Respublikos sveikatos apsaugos ministro 2008 m. gegužès 29 d. ịsakymas Nr. V-513 „Dèl Valstybinès šeimos sveikatos 2008-2010 metų programos patvirtinimo“. Valstybès žinios. 2008, Nr. 65-2475.

27. Lietuvos Respublikos sveikatos apsaugos ministro 2010 m. rugpjūčio 16 d. ịsakymas Nr. V-729,„Dèl pacientų siuntimo konsultuotis, išsitirti ir gydytis Europos ekonominei 
erdvei priklausančiose valstybėse ir Šveicarijoje tvarkos aprašo patvirtinimo“. Valstybés žinios. 2010, Nr. 99-5162.

28. Lietuvos Respublikos sveikatos apsaugos ministro $2012 \mathrm{~m}$. spalio $18 \mathrm{~d}$. ịsakymas Nr. V-938 „Dèl nacionalinio veiklos, susijusios su retomis ligomis, plano patvirtinimo“. Valstybès žinios. 2012, Nr. 124-6239.

29. Lietuvos Respublikos sveikatos apsaugos ministro $2013 \mathrm{~m}$. liepos $23 \mathrm{~d}$. issakymas Nr. V-724 „Dèl Lietuvos Respublikos sveikatos apsaugos ministro 2010 m. rugpjūčio 16 d. i̇sakymo Nr. V-729 „Dèl Pacientų siuntimo konsultuotis, išsitirti ir (ar) gydytis Europos ekonominei erdvei priklausančiose valstybèse ir Šveicarijoje tvarkos aprašo patvirtinimo“" pakeitimo“. Valstybès žinios. 2013, Nr. 82-4099.

30. Lietuvos Respublikos sveikatos apsaugos ministro $2014 \mathrm{~m}$. gegužès $22 \mathrm{~d}$. ịsakymas Nr. V-601 „Dèl Visuotinio naujagimių tikrinimo dèl igimtų medžiagų apykaitos ligų tvarkos aprašo patvirtinimo“. Valstybès žinios. 2014, Nr. 2014-05759.

31. Lietuvos Respublikos sveikatos apsaugos ministro $2014 \mathrm{~m}$. birželio $10 \mathrm{~d}$. ịsakymas Nr. V-677 „Dèl Neurochirurgijos paslaugų optimizavimo 2014-2020 metų plano patvirtinimo“. Valstybès žinios. 2014, Nr. 2014-07605.

32. Lietuvos Respublikos Seimo Sveikatos reikalų komiteto $2014 \mathrm{~m}$. liepos $16 \mathrm{~d}$. sprendimas „Dèl neurochirurgijos paslaugų organizavimo“ [interaktyvus]. [žiūrèta 2014-08-25]. <www3.lrs.lt/docs2/HPIVCRZP.DOCX>.

33. Mačiulevičienè, R.; Jakušovaitė, I. Medicinos etikos problemos prenatalinėje diagnostikoje. Lietuvos akušerija ir ginekologija. 2008, 9(3): 218-226.

34. McCabe, C.; Bergmann, L.; Bosanquet, N.; Ellis, M.; Enzmann, H., von Euler, M., et al. Market and patient access to new oncology products in Europe: a current, multidisciplinary perspective. Annals of Oncology. 2009, 20(3): 403-412.

35. Narbekovas, A.; Obelenienė, B.; Juškevičius, K., et. al. Medicina, etika ir teisé apie žmogų iki gimimo. Mokslinè monografija. Kaunas: VDU, 2012.

36. Natz, A. Putting a value on drugs for rare diseases. MedNous. September 2012, p. 8-9. [interaktyvus]. [žiūrèta 2014-08-25]. <http://www.natz-law.com/en/wpcontent/uploads/sites/3/2013/04/EU-Orphan-drug-policy-Natz-Campion1.pdf $>$.

37. Orphanet Report Series - Lists of medicinal products for rare diseases in Europe [interaktyvus]. October 2013 [žiūrèta 2014-08-07]. <http://www.orpha.net/orphacom/ cahiers/docs/GB/list_of_orphan_drugs_in_europe.pdf $>$.

38. Posada de la Paz, M.; Groft, M.; Groft, S (ed.). Rare Diseases Epidemiology, Advances in Experimental Medicine and Biology. 2010, 686.

39. Abejotina, arvalstybè turètų skirtimilžiniškaslèšas rizikingiems vaistams kompensuoti. Sveikatos apsaugos ministerija [interaktyvus]. 2012-06-08 [žiūrèta 2014-06-07]. <http://www.sam.lt/popup2.php?ru=bS9tX2FydGljbGUvZmlsZXMvdl9hcnRpY2xl X3ByaW50LnBocA==\&tmpl_name=m_article_print_view\&article_id=2952>.

40. Serapinas, D. Prenatalinès diagnostikos medicininiai, etiniai ir teisiniai aspektai. Sveikatos mokslai. 2012, 22(3): 131-136.

41. Špokienè, I. Legal assessment of current situation on orphan patients in Lithuania. Medicina. 2008, 44(8): 571-576.

42. Špokienè, I. Retujų vaistų prieinamumo reglamentavimas sveikatos teisejje. Daktaro disertacija (01 S). Vilnius: MRU, 2009.

43. Špokienè, I. Retomis ligomis sergančių pacientų teisinès galimybės gydytis neregistruotais vaistais. Socialiniu mokslų studijos. 2010, 2(6): 207-225. 
44. Tarptautinis ekonominių, socialinių ir kultūrinių teisių paktas. Valstybès žinios. 2002, Nr. 77-3290; Europos socialinè chartija (pataisyta). Valstybés žinios. 2001, Nr. 49-1704.

45. ten Have, H. A. M. J.; ter Meulen, R. H. J.; van Leeuwen, E. Medicinos etika. Vilnius: Charibdè, 2003.

46. Tumienè, B.; Kučinskas, V. Retosios ligos Lietuvoje ir Europoje. Gydymo menas. 2008, 11/12: 25-27.

47. Utkus, A. Retosios ligos, ju fenomika ir genetinis konsultavimas. Habilitacijos procedūrai teikiamų darbų apžvalga. Biomedicinos mokslai (medicina) (07B) [interaktyvus]. Vilnius, 2009 [žiūrèta 2014-08-06]. < http://vddb.library.lt/fedora/get/ LT-eLABa-0001:E.02 2009 D_20090526_111352-29090/DS.005.0.01.ETD>.

48. Valstybinès ligonių kasos prie Sveikatos apsaugos ministerijos direktoriaus $2005 \mathrm{~m}$. lapkričio 22 d. įsakymas Nr. 1K-149, „Dèl Sprendimų dèl vaistų ir medicinos pagalbos priemonių labai retoms ligoms ir būklèms gydyti kompensavimo ir dẻl nenumatytų atvejų priemimo komisijos darbo reglamento patvirtinimo“. Valstybės žinios. 2005, Nr. 139-5037.

49. Visuotinè žmogaus teisių deklaracija. Valstybés žinios. 2006, Nr. 68-2497.

50. Zielonka, D.; Marcinkowski, J. T.; Klimberg A. J. Health policy and legal regulations concerning the functioning in society of individuals burdened with Huntington's disease and other rare diseases. Journal of Pre-Clinical and Clinical Research. 2013, 7(1): 27-31.

\title{
Lithuanian Health Policy in the Field of Rare Diseases: Existing Legal Situation and Problems
}

\author{
Indrè Špokienė \\ Mykolas Romeris University, Lithuania
}

Summary. Relying on the systematic, logical and analytical methods, national legislation, as well as on the research conducted by the Lithuanian and foreign scientists, this article deals with the ethical and legal peculiarities of Lithuanian health policy in the field of rare diseases and reveals related problems. Lithuanian health policy in the field of rare diseases is developed in two main directions: application of measures to prevent rare diseases and organization and systematic healthcare assistance to the affected persons.

The author in the article states that legal regulation of universal screening of newborns in Lithuania is effective, although, in comparison with other EU countries, newborns are screened for a small number of rare diseases (only two diseases: congenital hypothyroidism and phenylketonuria). After the evaluation of legal regulation of genetic consulting, the following weaknesses were envisaged: legally not-regulated pre-implantation method; there is no national legislation defining the legal status of unborn child; there is no legal definition of "abortion"; termination of human's life at prenatal stage is consolidated by the order of the 
Minister having the rank of secondary legislation. The following ethical objections were observed, as well: application of abortions to foetus that can be born with a disability; diagnosed incurable disease of unborn child as a way to offer abortion automatically calls into question the value of his life. These weaknesses are proposed to be corrected via adoption of Law on Protection of Human Life in the Prenatal Phase; the doctors are recommended to strictly follow the principles of genetic consulting ethics.

The second health policy direction in the field of rare diseases is implemented using three measures: through the organization of personal healthcare service system; through the accessibility of healthcare services abroad and accessibility of medicines for patients suffering from rare diseases. It was concluded that personal healthcare service system for patients with rare diseases in Lithuania still does not work harmoniously. In order to improve the situation, it is proposed to revise the payment system currently functioning for the provision of personal healthcare services for the patients with rare diseases, as well to start the monitoring of rare diseases at the national scale. It has been determined that the legal regulations of the $E U$ on cross-border provision of healthcare services to patients are implemented to the national law properly, however, the procedure related to the issue of permits for the patients to receive such services provides no specific exceptions for the patients with rare diseases. The analysis of legal regulation on the current accessibility to the medicine necessary to cure rare diseases states that Lithuania has conditions to supply orphan medicinal products to the Lithuanian market established. Essential weakness is that the so-called "compassionate use of medicinal products" has not been validated yet. The ethical problems are caused by the lack of reimbursement for orphan medicinal products, repeated procedures related to the evaluation of efficiency and therapeutic value of the orphan medicines at the national competent institutions.

Keywords: rare diseases, orphan medicinal products, rare diseases policy in Lithuania, health policy in the field of rare diseases, rights of patient's suffering from rare diseases.

Indrè Špokienė, Mykolo Romerio universiteto Teisès fakulteto Teisès filosofijos ir istorijos katedros docentè. Mokslinių tyrimų kryptys: sveikatos teisès teorinès ir praktinès problemos, biomedicinos ir biotechnologijų pasiekimų ịtaka žmogaus teisių apsaugai.

Indrè Špokienė, Mykolas Romeris University, Faculty of Law, Department of Philosophy of Law and Legal History, Associate Professor. Research interests: theoretical and practical problems of health law, the impact of biomedicine and biotechnology development on human rights. 